\title{
Pengaruh Elemen Sensory Branding Terhadap Perilaku Pengambilan Keputusan Konsumen Dalam Membeli Aqua Dengan Pendekatan Neuromarketing Di Kabupaten Jember
}

\section{The Impact of Sensory Branding's Elements on Consumer's Decision Making Behavior of Buying Aqua With Neuromarketing Approach In Jember}

\author{
Dimas Khurniawan, Deasy Wulandari ${ }^{1}$, Mohammad Dimyati \\ Jurusan Manajemen, Fakultas Ekonomi, Universitas Jember (UNEJ) \\ Jln. Kalimantan 37, Jember 68121 \\ E-mail: dimaskhurniawan@icloud.com
}

\begin{abstract}
Abstrak
Tujuan dari penelitian ini adalah untuk mengetahui pengaruh elemen sensory branding terhadap perilaku pengambilan keputusan konsumen dalam membeli Aqua di Kabupaten Jember. Populasi dari penelitian ini merupakan konsumen Aqua di Kabupaten Jember. Penelitian ini menggunakan metode purposive sampling dengan jumlah responden sebanyak 100 orang. Instrumen analisis yang digunakan dalam penelitian ini adalah Structural Equation Model (SEM) dengan pendekatan confirmatory. Hasil analisis menunjukkan bahwa: 1) Ada pengaruh signifikan auditory terhadap perilaku pengambilan keputusan konsumen dalam membeli Aqua di Kabupaten Jember, 2) Ada pengaruh signifikan visual terhadap perilaku pengambilan keputusan konsumen dalam membeli Aqua di Kabupaten Jember, dan 3) Ada pengaruh signifikan tactile terhadap perilaku pengambilan keputusan konsumen dalam membeli Aqua di Kabupaten Jember.
\end{abstract}

Kata Kunci: Aqua, Neuromarketing, Perilaku Konsumen, Pengambilan Keputusan dan Sensory Branding.

\section{Abstract}

The purpose of this study acclaims the important of Auditory, Visual and Tactile in affecting consumer's decision making behavior of buying, it is also to figure out it's impact in Aqua. Thus, it is important to study "The Impact Of Sensory Branding's Elements On Consumer's Decision Making Behavior Of Buying Aqua With Neuromarketing Approach In Jember". The population in this study are Aqua's consumers in Jember. Sampling is taken using purposive sampling method from 100 respondents. Instrument analysis in this study is performed using Structural Equation Model (SEM) with confirmatory approach. The result shows that: 1) auditory significantly affects consumer's decision making behavior of buying Aqua in Jember, 2) visual significantly affects consumer's decision making behavior of buying Aqua in Jember, and 3) tactile significantly affects consumer's decision making behavior of buying Aqua in Jember.

Keywords: Sensory Branding, Neuromarketing, Consumer Behaviour, Decision Making and Aqua.

\section{Pendahuluan}

Seorang filsuf Yunani kuno, Plato, mengutarakan suatu filosofi yang menegaskan bahwa manusia dalam aktifitasnya dikendalikan oleh 2 sistem yang menghubungkan seseorang dengan jiwanya (pikiran). Sistem tersebut dikenal dengan nama filsafat Plato "Kereta yang Ditarik oleh 2 Kuda (Plato's chariot-drawn-by-two-horses philosophy)" yaitu sistem 1 (emosi) dan sistem 2 (akal pikiran). Kereta kuda yang ditarik oleh 2 ekor kuda dalam analogi tersebut maksudnya adalah kuda 1 sebagai sistem 1 dan kuda 2 sebagai sistem 2. Keseluruhan proses tersebut memandu konsumen dalam menentukan keputusan pembelian suatu produk, namun keputusan pembelian secara kompulsif dan ataupun spontan dikendalikan oleh sistem 1 (Zurawicki, 2010:88).

Premis teori ekonomi klasik menyatakan bahwa manusia merupakan makhluk yang rasional yang selalu mengikuti keinginannya sendiri dan berbasiskan pada pengambilan keputusan yang berdasarkan pada pemikiran rasional yang secara akurat dapat menaksir berbagai pilihan yang ada (Fehr, 2006:47).

1 Corresponding Author
Strategi branding dalam neuromarketing yang dikenal dengan "Sensory Branding" telah banyak diterapkan oleh perusahaan-perusahaan besar. Tujuannya adalah untuk menciptakan koneksi emosional yang lebih kuat dengan konsumen. Penerapan strategi sensory branding dalam neuromarketing melawan teori pemasaran klasik yang menyebutkan bahwa keputusan pembelian yang dilakukan oleh konsumen berdasarkan pada sistem 2 yaitu keputusan yang hanya bersifat rasional. Teori neuromarketing menyatakan bahwa sistem 1 lah yang memiliki peranan masif dalam pembentukan keputusan pembelian oleh konsumen. Renvoise (2007:138) dalam bukunya Neuromarketing: Understanding The Buy Buttons in Your Customer's Brain menambahkan bahwa marketing telah mati dan digantikan oleh neuromarketing.

Aqua merupakan salah satu produk air mineral dalam kemasan yang merupakan bagian dari Danone Group dan telah banyak dikenal oleh masyarakat Indonesia khususnya di Kabupaten Jember. Strategi branding dalam penetapan positioning di pasar yang diterapkan oleh Aqua telah menempatkan Aqua sebagai produk minuman mineral kemasan yang memorable dan sangat melekat dalam benak 
konsumen di Jember. Aqua terfokus pada promosi branding secara visual melalui design, hal tersebut dapat dilihat dari hasil komitmen Aqua dengan mendapatkan penghargaan Indonesia Good Design Selection (IGDS) untuk Gold Award Design terbaik Indonesia Tahun 2011 untuk kategori produk industri massal dan telah dipasarkan dari Kementrian Perindustrian. Perhatian strategi branding Aqua secara visual juga diimplementasikan dalam peluncuran produk "Aqua Refleksion" dengan menggunakan tampilan visual kemasan berupa botol yang elegan serta menambahkan design pola batik yang merupakan hasil karya seni dari Sebastian Gunawan. Aqua dari segi auditory juga memiliki jingle yang diputar pada setiap iklan yang ditampilkannya. Aqua juga memiliki berbagai bentuk kemasan mulai dari kemasan botol berbahan plastik yang ringan sampai kemasan galon yang memiliki bobot cukup berat.

Berdasarkan fakta-fakta tersebut, maka permasalahan yang akan diteliti dalam penelitian ini dapat dirumuskan bahwa apakah elemen sensory branding (auditory, visual dan tactile) berpengaruh signifikan terhadap perilaku pengambilan keputusan konsumen dalam membeli Aqua dengan pendekatan neuromarketing di Kabupaten Jember. Tujuan dari penelitian ini adalah untuk menguji pengaruh signifikan elemen sensory branding (auditory, visual dan tactile) terhadap perilaku pengambilan keputusan konsumen dalam membeli Aqua dengan pendekatan neuromarketing di Kabupaten Jember. Hipotesis dari penelitian ini adalah :

1. Auditory berpengaruh signifikan terhadap perilaku pengambilan keputusan konsumen dalam membeli Aqua dengan pendekatan neuromarketing di Kabupaten Jember

2. Visual berpengaruh signifikan terhadap perilaku pengambilan keputusan konsumen dalam membeli Aqua dengan pendekatan neuromarketing di Kabupaten Jember

3. Tactile berpengaruh signifikan terhadap perilaku pengambilan keputusan konsumen dalam membeli Aqua dengan pendekatan neuromarketing di Kabupaten Jember.

\section{Metode}

\section{Rancangan Penelitian}

Penelitian ini merupakan penelitian konfirmatori (confirmatory research).

\section{Jenis dan Sumber Data}

Jenis data yang digunakan dalam penelitian ini adalah data primer dan diperoleh melalui penyebaran kuesioner kepada konsumen Aqua di Kabupaten Jember.

\section{Populasi dan Sampel}

Populasi dalam penelitian ini adalah konsumen Aqua di Kabupaten Jember. Penetapan sampel dalam penelitian ini sebanyak 100 responden. Penelitian ini menggunakan teknik purposive sampling dengan kriteria :

1. Pengambilan sampel meliputi 3 Kecamatan di Kabupaten Jember yaitu Kecamatan Sumbersari, Kaliwates dan Patrang, dengan asumsi bahwa responden yang berdomisili di tiga Kecamatan tersebut merupakan masyarakat perkotaan yang memiliki unsur heterogen sehingga dapat mewakili populasi.

2. Responden merupakan konsumen Aqua yang bertempat tinggal di Jember dan pernah melakukan pembelian produk Aqua minimal satu kali.

3. Responden tidak memiliki gangguan neurologis dan berada dalam kondisi pikiran yang normal (normal state of mind)

\section{Metode Analisis Data}

Metode analisis data yang digunakan dalam penelitian ini yaitu CFA (confirmatory factor analysis) untuk menguji validitas dan reliabilitas instrumen penelitian serta analisis SEM (structural equation model) untuk uji asumsi dan uji kausalitas.

\section{Hasil dan Pembahasan}

\section{Hasil}

\section{Deskripsi Variabel Penelitian}

Jumlah data dalam penelitian ini sebanyak 100. Variabel auditory $\left(\mathrm{X}_{1}\right)$ mempunyai rata-rata 4,17 , dengan nilai minimal 3 dan maksimal 5, sedangkan standar devisiasinya sebesar $0,41 \%$. Variabel visual $\left(\mathrm{X}_{2}\right)$ mempunyai rata-rata sebesar 4,24, dengan nilai minimal 3,75 dan maksimal 5, sedangkan standar devisiasinya sebesar $0,27 \%$. Variabel tactile $\left(\mathrm{X}_{3}\right)$ mempunyai rata-rata sebesar 4,19 , dengan nilai minimal 3,5 dan maksimal 4,19, sedangkan standar devisiasinya sebesar $0,3,6 \%$. Variabel perilaku pengambilan keputusan (Y) mempunyai rata-rata sebesar 4,19, dengan nilai minimal 3,5 dan maksimal 5, sedangkan standar devisiasinya sebesar $0,35 \%$.

\section{Karakteristik Responden}

Responden dalam penelitian ini adalah semua konsumen Aqua di Kabupaten Jember yang berjumlah 100 responden.

Tabel 1. Data Responden Berdasarkan Jenis Kelamin

\begin{tabular}{ccc}
\hline Jenis Kelamin & $\begin{array}{c}\text { Jumlah } \\
\text { Responden }\end{array}$ & Proporsi \\
\hline Pria & 73 & $73 \%$ \\
\hline Wanita & 27 & $27 \%$ \\
\hline Jumlah & 100 & $100 \%$ \\
\hline
\end{tabular}

Sumber: data primer, 2015.

Mayoritas responden yang menjadi pengambil keputusan pembelian Aqua di Jember adalah responden yang berjenis kelamin pria, sedangkan responden paling sedikit yang menjadi pengambil keputusan pembelian Aqua di Jember adalah responden yang berjenis kelamin wanita.

Tabel 2. Data Responden Berdasarkan Usia

\begin{tabular}{cc}
\hline Usia & Jumlah \\
\hline $16-21$ & 6 \\
$21-30$ & 48 \\
$31-40$ & 35 \\
$>41$ & 11 \\
\hline Total & 100 \\
\hline
\end{tabular}

Sumber: data primer, 2015.

Karakteristik responden berdasarkan usia ditampilkan pada Tabel 2. Responden terbanyak yang menjadi pengambil keputusan pembelian Aqua di Jember adalah responden yang berusia diantara 21-30 tahun, sedangkan responden paling 
sedikit yang menjadi pengambil keputusan pembelian Aqua di Jember adalah responden yang berusia 16-20 tahun, 31-40 tahun dan diatas 41 tahun.

\section{Tabel 3. Data Responden Berdasarkan Profesi}

\begin{tabular}{cc}
\hline Profesi & Jumlah \\
\hline Pelajar / Mahasiswa & 28 \\
Pegawai Swasta & 26 \\
Pegawai Negeri & 5 \\
Wiraswasta & 41 \\
\hline Total & 100
\end{tabular}

Sumber: data primer, 2015.

Tabel 3 menunjukkan bahwa responden terbanyak yang menjadi pengambil keputusan pembelian Aqua di Jember adalah responden yang berprofesi sebagai Wiraswasta, sedangkan responden paling sedikit yang menjadi pengambil keputusan pembelian Aqua di Jember adalah responden yang beprofesi sebagai Pelajar / Mahasiswa, Pegawai Swasta, dan Pegawai Negeri.

\section{Distribusi Jawaban Responden}

Distribusi jawaban responden pada variabel auditory $\left(\mathrm{X}_{1}\right)$ yaitu:

a. Pada pertanyaan indikator $X_{1.1}$, musik, 100 responden diketahui bahwa 2\% menjawab netral, $72 \%$ menjawab setuju, dan 26\% menjawab sangat setuju. Hal ini menunjukkan bahwa mayoritas responden menjawab setuju dan responden memiliki persepsi yang baik terhadap indikator musik;

b. Pada pertanyaan indikator $\mathrm{X}_{1.2}$, noise, 100 responden diketahui bahwa $8 \%$ menjawab netral, $74 \%$ menjawab setuju, dan $18 \%$ menjawab sangat setuju. Hal ini menunjukkan bahwa mayoritas responden menjawab setuju dan responden memiliki persepsi yang baik terhadap indikator noise.

Distribusi jawaban responden pada variabel visual $\left(\mathrm{X}_{2}\right)$ yaitu:

a. Pada pertanyaan indikator $\mathrm{X}_{2.1}, \operatorname{logo}, 100$ responden diketahui bahwa $70 \%$ menjawab setuju, dan $30 \%$ menjawab sangat setuju. Hal ini menunjukkan bahwa mayoritas responden menjawab setuju dan responden memiliki persepsi yang baik terhadap indikator logo;

b. Pada pertanyaan indikator $\mathrm{X}_{2.2}$, warna, 100 responden diketahui bahwa $2 \%$ menjawab netral, $81 \%$ menjawab setuju, dan $17 \%$ menjawab sangat setuju. Hal ini menunjukkan bahwa mayoritas responden menjawab setuju dan responden memiliki persepsi yang baik terhadap indikator warna;

c. Pada pertanyaan indikator $X_{2.3}$, cahaya, 100 responden diketahui bahwa 2\% menjawab netral, $80 \%$ menjawab setuju, dan $18 \%$ menjawab sangat setuju. Hal ini menunjukkan bahwa mayoritas responden menjawab setuju dan responden memiliki persepsi yang baik terhadap indikator cahaya;

d. Pada pertanyaan indikator $\mathrm{X}_{2.4}$, desain, 100 responden diketahui bahwa $62 \%$ menjawab setuju, dan $38 \%$ menjawab sangat setuju. Hal ini menunjukkan bahwa mayoritas responden menjawab setuju dan responden memiliki persepsi yang baik terhadap indikator desain.

Distribusi jawaban responden pada variabel tactile $\left(\mathrm{X}_{3}\right)$ yaitu:

a. Pada pertanyaan indikator $\mathrm{X}_{3.1}$, material, 100 responden diketahui bahwa $80 \%$ menjawab setuju, dan $20 \%$ menjawab sangat setuju. Hal ini menunjukkan bahwa mayoritas responden menjawab setuju dan responden memiliki persepsi yang baik terhadap indikator material;

b. Pada pertanyaan indikator $\mathrm{X}_{3.2}$, temperatur, 100 responden diketahui bahwa 1\% menjawab netral, $80 \%$ menjawab setuju, dan 19\% menjawab sangat setuju. Hal ini menunjukkan bahwa mayoritas responden menjawab setuju dan responden memiliki persepsi yang baik terhadap indikator temperatur. Terdapat seorang responden yang menjawab netral terhadap suhu, hal tersebut dapat diartikan bahwa suhu atau temperatur produk Aqua yang responden sentuh tidak menjadi pertimbangan namun disaat tertentu juga menjadi pertimbangan responden dalam memilih, karena hal tersebut didasarkan pada kondisi situasional responden yang menginginkan suhu atau temperatur tertentu disaat tertentu pula.

Distribusi jawaban responden pada variabel perilaku pengambilan keputusan (Y) yaitu:

a. Pada pertanyaan indikator $\mathrm{Y}_{1}$, emosi, 100 responden diketahui bahwa $75 \%$ menjawab setuju, dan $25 \%$ menjawab sangat setuju. Hal ini menunjukkan bahwa, mayoritas responden menjawab setuju dan responden memiliki persepsi yang baik terhadap indikator emosi;

b. Pada pertanyaan indikator $\mathrm{Y}_{2}$, kognitif, 100 responden diketahui bahwa $2 \%$ menjawab netral, $82 \%$ menjawab setuju, dan 16\% menjawab sangat setuju. Hal ini menunjukkan bahwa, mayoritas responden menjawab setuju dan responden memiliki persepsi yang baik terhadap indikator kognitif. Terdapat 2 responden yang menjawab netral, hal tersebut dapat diartikan bahwa ketika kedua responden tersebut memutuskan untuk membeli produk Aqua, responden melakukan pertimbangan kognitif secara sadar namun pertimbangan tersebut melibatkan kondisi emosionalnya sebagai pembanding alternatif.

\section{Pembahasan}

Stimulus-stimulus auditory yang terdiri dari musik dan noises ditangkap melalui panca indera pendengaran konsumen. Stimulus-stimulus tersebut terdeteksi oleh sel rambut yang berada di Cochlea bagian dalam telinga konsumen. Tahap selanjutnya adalah neuron dari saraf auditory bergerak membawa informasi suara tersebut melalui Thalamus menuju Temporal Gyrus yang merupakan bagian dari Cerebral Cortex yang terlibat dalam penerimaan dan pembentukan persepsi suara. Informasi suara tersebut kemudian terkumpul di cortex yang melakukan berbagai aktifitas yang dapat memunculkan pengenalan suara (sound recognition), sehingga dengan mendengarkan suara-suara random (noises) di tempat Aqua tersebut dijual maka akan memberikan pengenalan suara dalam benak konsumen bahwa Aqua merupakan produk yang memiliki ciri khas yang mengingatkannya dengan kenangan yang pernah dialami. Hal tersebut akan mendorong adanya pembentukan proses berfikir konsumen secara rasional dalam menentukan dan mempertimbangkan perilaku pengambilan keputusan pembeliannya terhadap produk Aqua, serta adanya pelanggan yang pernah atau selalu mendengarkan musik dari Aqua akan mengaktifkan Amygdala yaitu bagian otak yang berperan dalam mengatur emosi, sehingga dapat membangkitkan mood konsumen dan mendorong konsumen untuk merasakan rasa 
senang ketika mengkonsumsi Aqua. Hal tersebut akan mendorong adanya proses emosional dalam menentukan perilaku pembeliannya terhadap Aqua. Bagian yang paling aktif dari otak konsumen remaja ialah superior temporal sulcus yang berfungsi dalam proses pengolahan perilaku aksi yang fundamental sehingga remaja cenderung untuk tidak berfikir panjang, lebih terfokus pada diri sendiri dan sulit untuk memahami konsekuensi dari aksi yang dilakukannya. Di sisi lain, bagian yang paling aktif dari otak konsumen dewasa ialah prefrontal cortex yang berfungsi dalam proses pengolahan pengambilan keputusan yang lebih kompleks karena melibatkan pertimbangan konsekuensi bagi orang lain. Sehingga konsumen remaja lebih cenderung untuk menggunakan proses emosionalnya dalam membuat keputusan, hal tersebut kontras dengan konsumen dewasa yang lebih cenderung menggunakan proses kognitifnya. Hasil penelitian menunjukkan bahwa mayoritas responden adalah konsumen remaja sehingga ketika konsumen remaja mendengarkan stimulus auditory dari Aqua maka mereka lebih cenderung untuk tidak berfikir panjang dan mendorong munculnya proses emosional dalam pengambilan keputusan pembelian Aqua. Hasil dari penelitian ini mendukung temuan yang dilakukan oleh Rieunier (2009) yang menyatakan bahwa auditory dapat digunakan untuk mempengaruhi perilaku pembelian oleh konsumen.

Visual sebagai warna dan bentuk yang merupakan cara pertama dalam menentukan diferensiasi dan identifikasi pada beberapa merek dan diasosiasikan dengan warna tertentu yang kemudian diingat dengan mudah oleh konsumen melalui alam bawah sadarnya. Adanya konsumen yang dapat melihat warna biru yang melekat pada Aqua dan kemudian mengasosiasikannya dengan simbol kepercayaan (trust), otoritas dan keamanan telah memberikan penilaian melalui alam bawah sadar konsumen bahwa Aqua merupakan produk yang aman dan dapat dipercaya untuk dikonsumsi. Hal tersebut mendorong adanya proses emosional dalam menentukan perilaku pengambilan keputusan pembelian konsumen terhadap Aqua. Adanya konsumen yang dapat membedakan produk Aqua dengan produk lain dengan melihat logo Aqua telah menjadikan konsumen mengetahui bahwa produk Aqua memiliki diferensiasi yang dapat diketahui dari sebuah simbol mereknya sehingga dengan perbedaan yang ada maka konsumen akan mengetahui dan memudahkan dalam mengidentifikasikan produk Aqua dengan produk lain. Hal tersebut akan mendorong adanya pembentukan proses berfikir konsumen secara rasional dalam menentukan dan mempertimbangkan perilaku pengambilan keputusan pembeliannya terhadap produk Aqua. Adanya konsumen yang mampu memperhatikan intensitas gelap terang cahaya dalam menerangi sebuah produk Aqua yang dilihatnya maka akan meningkatkan sensasi diri serta lama waktu konsumen berada di toko, sehingga konsumen memiliki lebih banyak waktu untuk berfikir. Hal tersebut mendorong adanya pembentukan proses berfikir konsumen secara rasional dalam menentukan dan mempertimbangkan perilaku pengambilan keputusan pembeliannya terhadap roduk Aqua. Adanya konsumen yang mampu memperhatikan design atau layout tata letak penempatan produk Aqua yang dilihatnya maka akan meningkatkan citra merek dan kualitas dari Aqua yang dipersepsikan, sehingga tanpa disadari konsumen akan merasakan kualitas yang baik dari Aqua. Hal tersebut mendorong adanya pembentukan proses emosional konsumen secara tidak rasional dalam menentukan perilaku pengambilan keputusan pembeliannya terhadap produk Aqua. Konsumen wanita lebih cenderung terpengaruh oleh proses emosionalnya dalam memutuskan pembelian dari pada konsumen pria jika dihadapkan pada stimulus penglihatan, hal tersebut disebabkan karena konsumen wanita lebih cenderung mengasosiasikan sesuatu yang dilihatnya dengan dirinya sendiri, namun dalam hal ini tidak banyak informasi visual pada produk Aqua yang dapat diasosiasikan dengan feminitas atau sifat kepribadian wanita, sehingga konsumen Aqua yang berjenis kelamin wanita cenderung untuk lebih menggunakan proses kognitifnya. Disisi lain, meskipun konsumen pria lebih cenderung menggunakan sisi kognitifnya, hal tersebut tidak lantas membuat konsumen pria hanya melulu terpengaruh oleh proses rasionalnya saja, karena Plato secara filosofis menyampaikan bahwa manusia sebagai konsumen (pria maupun wanita) juga digerakkan oleh proses emosionalnya. Hal tersebut dapat dilihat bahwa mayoritas konsumen yang menjadi responden dalam penelitian ini adalah pria dan jawaban keseluruhan responden cenderung lebih melibatkan proses emosionalnya. Sehingga, hasil dari penelitian ini mendukung temuan yang dilakukan oleh Lindstrom (2005) yang menyatakan bahwa representasi visual dari merek mempengaruhi perilaku pengambilan keputusan pembeli.

Tactile sebagai stimulus sentuhan dari produk Aqua ditangkap oleh reseptor indera peraba konsumen Aqua di Jember. Adanya pelanggan yang dapat atau selalu menyentuh kemasan dari produk Aqua untuk mengetahui tekstur kemasan Aqua yang akan dibelinya telah membangun persepsi konsumen terhadap produk. Sehingga secara emosional konsumen akan semakin terikat dan berkeinginan untuk membeli Aqua. Hal tersebut mendorong adanya pembentukan proses emosional konsumen secara tidak rasional dalam menentukan perilaku pengambilan keputusan pembeliannya terhadap roduk Aqua. Adanya pelanggan yang dapat atau selalu menyentuh kemasan dari produk Aqua untuk mengetahui temperatur dari produk Aqua yang akan dibelinya telah meningkatkan rekognisi konsumen terhadap Aqua, sehingga konsumen dapat mengenali kualitas Aqua yang akan dibelinya. Hal tersebut mendorong adanya pembentukan proses kognitif konsumen secara rasional dalam menentukan dan mempertimbangkan perilaku pengambilan keputusan pembeliannya terhadap roduk Aqua. Sehingga, hasil dari penelitian ini mendukung temuan yang dilakukan oleh Hulten (2013) yang dalam penelitiannya menyimpulkan bahwa sentuhan (tactile) terhadap produk mempengaruhi perilaku pembelian konsumen.

\section{Simpulan}

Hasil analisis dalam penelitian ini menerima ketiga hipotesis alternatif sehingga dapat disimpulkan bahwa elemen sensory branding (auditory, visual dan tactile) berpengaruh signifikan terhadap perilaku pengambilan keputusan konsumen dalam membeli Aqua dengan pendekatan neuromarketing di Kabupaten Jember dengan arah positif. Hal ini membuktikan bahwa dengan adanya auditory, visual dan tactile maka akan meningkatkan adanya perilaku pengambilan keputusan konsumen dalam melakukan pembelian.

\section{Referensi}

Anonim. 2014. Aqua (Air Mineral), http://id.wikipedia.org/wiki/Aqua \%28air_mineral\%29, Diakses Senin 25 November 2014. 
Anonim. 2014. Aqua Danone Group, http://www.danone.com/en/for-all/our4-business-lines/waters/our-brands/buid/aqua/, Diakses Senin 25 November 2014.

Anonim.2013.Neuromarketing,http://en.m.wikipedia.org/wiki/neuromarketin g, april 2013, diakses Senin 25 November 2014.

Anonim. 2014. http://aqua.com, Diakses Senin 25 November 2014.

Belden, S.R.A. 2008. Neuroeconomics And Neuromarketing. Practical Applications And Ethical Concerns. Journal of Mind Theory. Vol. 0, No. 2, pp. 249-258.

Fehr, E. dan Camerer, C.F. 2006. When Does Economic Man Dominate Social Behaviour?. Journal of Science, Vol 311, No. 5757, pp. 47-52.

Lindstrom, M. 2005. Brandsense: Build Powerful Brands Through Touch,
Taste, Smell, Sight and Sound. New York: Free Press.

Lindstrom, M. 2008. Buy-ology: Truth and Lies About Why We Buy. New York: Doubleday.

Lindstrom, M. 2011. Brandwashed: Tricks Companies Use to Manipulate Our Minds and Persuade Us to Buy. New York: Crown Business.

Morin, C. 2011. Neuromarketing: The New Science of Consumer Behaviour. San Anselmo US: Springer.

Renvoise, P. dan Morin, C. 2007. Neuromarketing: Understanding The Buy Button in Your Customer Brain. Nashville Tennessee: Thomas Nelson.

Rieunier, S. 2009. Le Marketing Sensoriel Du Point Du Vente. Paris: Dunod.

Zurawicki, L. 2010. Neuromarketing: Exploring The Brain of The Consumer. London, UK: Springer. 